\title{
Real Time Dynamic Analysis of Solar PV Integration for Energy Optimization
}

\author{
Kenneth E. Okedu*, A. Al Senaidi*, I. Al Hajri*, I. Al Rashdi* and W. Al Salmani* \\ *Department of Electrical and Communication Engineering \\ National University of Science and Technology, PC 111, Muscat, Sultanate of Oman \\ (okedukenneth@nu.edu.om, abdulaziz180300@nu.edu.om, imaduddin120205@nu.edu.om, issa120457@nu.edu.om, and waleed03035@nu.edu.om)
}

\author{
$\$$ Corresponding Author, Kenneth E. Okedu, Tel: +968 91446270 \\ okedukenneth@nu.edu.om or kenokedu@yahoo.com
}

Received: 10.02.2020 Accepted:10.06.2020

\begin{abstract}
Currently, electricity production in Oman depend on non-renewable energy resources such as oil and gas. However, there are some limitations and challenges using these sources. As they are non-renewable energy resources, they may not be available in the future. Besides, they are harmful to the environment and contribute to global warming. Therefore, it is necessary to consider the use of renewable energy resources like solar energy for electricity generation, because they are clean and ecofriendly. Oman is one of the most important countries in the world for the real application of solar energy, as it has appropriate geographical and environmental characteristics. This study considered real time dynamic analysis of integrating solar PV in the Sultanate of Oman grid system. The analysis was done for three periods considering the months in the begining, middle and end of the considered year of the study. The meteoroligical monitoring system for solar PV plants platform was used for the analysis of the various variables of the solar grid connected model. The obtained results show that the power generated and consumed using the solar PV differ throughout the year and this could help for future load forecast and to properly optimize the use of generated power. The PV measurements obatined in this work could be processed for a future perspective concerning the realization of a PV microgrid with an optimized energy management system.
\end{abstract}

Keywords Renewable energy; solar PV; grid network; solar power, loads.

\section{Introduction}

Oil is currently the mainstay of the global economy. With the recent development in technology, the demand of oil or fossil fuel has increased in order to meet the energy needs of industrial processes. The huge dependence on this energy source has a lot of negative effects. Environmental pollution from the burning of fossil fuel leads to global warming issue [1]. Also, there are possibilities of depletion of fossil fuel in the future, hence it has limited use. Besides, the current instability of oil price has impact on the global energy markets, affecting the economy of both producing and consuming countries [2].

In light of the above, the alternative or renewable energy sources like sun, wind, waves, tides, and biomass are recently gaining attention in many countries, for the production of electricity. In the same vein, Oman is not left out. Lately, Oman is making great effort in the utilization of renewable energy resources as seen in the Amal East and
West projects $[3,4]$, where the current largest world solar farm is been built. Also, in Salalah, the ongoing wind farm project is one of the largest in the world [5], with high chances of generating employments for the citizenry of the country [6]. Studies in the literature have shown that, Oman's geographical structure, long coastline and high reach of sun radiation qualifies it to be a great example in the use of renewable energy resources, for electrical power generation $[7,8]$.

According to the authority for population and economic growth in Oman, the demand of energy required in the country is on the rise on a daily basis. Therefore, it is necessary to augment the expensive fossil powered plants with renewable energy resources, in order to encourage mix power generation and the continuity of the power supply at a lower cost. A study conducted by the Authority of Electricity Regulation- Oman, in 2008 [9] reported that, it is imperative to integrate renewable energy into the national grid for electricity production, considering economic and 
environmental issues. Reference [10] presented a research on the availability of renewable energy resources in Oman like solar, wind, hydro, geothermal and biomass for electricity production. However, the authors failed to address the evaluation and integration of solar renewable sources considering the different geographical locations of the country and real time dynamic analysis.

Electricity system in Oman market structure consists of three main market companies which are: The Main Interconnected System (MIS), rural system and Salalah power system [5]. Based on [9], the peak forecast demand of electricity by MIS will increase from $2773 \mathrm{MW}$ in 2007 to $6634 \mathrm{MW}$ in 2018, and this increased should be augmented by the use of renewable energy sources. Also, the 2015 report of the Oman Power and Water Procurement Company, shows that the growth of electricity demand for the MIS Muscat Governorate, North and South Al-Batinah Governorate, North and South Al-Sharqiay Governorate, AlDakhlia and Al-Thahera Governorate will increase during the next seven years from 2015 to 2021 by percentage of $7-11 \%$ [11]. The issues and the challenges that face renewable energy in Oman were discussed in [12], and it was suggested that a clean and efficient energy that is sustainable in the Sultanate should be encourage by forming a sector that is well organized by policies and technologies.

Furthermore, the International Renewable Energy Agency report in 2018 [13], shows that, $97 \%$ of natural gas is used for electricity production and $3 \%$ by diesel in the Sultanate of Oman. The agency expects good range of renewable energy resources to partake in the energy mix for generating electricity in the country. In another study carried out by Oxford Institute for Energy Studies [14], about the renewable energy sources in Gulf Cooperation Council (GCC) states, shows the range of $\mathrm{CO}_{2}$ emissions through Oman and the GCC states at high rates. The study finalized that the GCC countries are rich in non-renewable energy sources and contributes to increase of the global warming issue.

It was reported in $[15,16]$ that solar energy is the highest available renewable sources in Oman, followed by wind energy. The key findings of the feasibility study carried out in the literature shows that the sun radiations fall in all parts of Oman for 342 days. However, the feasibility of wind energy along the coastline areas and southern mountains of Oman is very high. Also, the International Renewable Energy Agency in 2013 [17] and 2016 [18], respectively supported the facts of good range of solar and wind energy resources applicable in Oman. In these reports, the sun radiation density is considered to be the highest around the world than the wind energy in the coastline areas and southern parts of Oman. According to [19], from 10, June 2010 to 10 , December 2010, the study conducted in Oman by surf-forecast.com shows the wave size and wind speed across different places and is expected to increase in summer periods.

The economic feasibility of the transition to renewable energy carried out by references [20-24], confirmed that the investments of renewable energy in Oman will increase revenues, because research and industrial activities connected to this field will encourage new manufactures. Additionally, this will lead to more external attractive investments and export surplus of electricity. As expected, there will be competitive costs between the electricity generated by renewable energy resources and the fossil fuels. The reports presented by [9] and [12] agree with the study by [17], about the economic chances and investment in renewable energy sector of the Sultanate of Oman.

The challenges facing the use of renewable energy highlighted in the literature [16, 25, and 26], show that there is a good economic feasibility to use renewable energy in Oman, instead of fossil fuel resources, but the current investments in this sector are very less and the development is at slow rate. This is mainly due to the absence of organized policies and less experts in this field. There are more expenses paid for research about new fossil fuelled-wells and less attention to invest on renewable energy. For instance, more quantities of water are required to clean the solar cells at desert areas in order to gain efficient performance of the solar cells. However, Oman does not contain high amount of clean water at the current times because it is located in the desert as reported by reference [12].

This paper presents the real time dynamic analysis of the integration of solar energy into the grid network of the Sultanate of Oman. The study is done based on the drive for the implementation of solar energy system projects by Shell Petroleum Company as a gift to schools in Oman. This is in collaboration with the headquarters of the Ministry of Higher Education (MOHE), to cover schools by installing solar photovoltaic system, in each governorate of the country. The key focus of this study was carried out using the Kaab bin Barsha School. The study also considered different months of the year having different radiations, and also the load demand based on schools been on holidays and on session in order to analysis the real time behaviour of the system dynamics. The study was able to help understand the percentage of solar energy required for different times of operation, in order to help optimize how electricity production and consumption should be fully optimized by selling or buying from the local grid. The PV measurements obatined in this work could be processed for a future perspective concerning the realization of a PV microgrid with an optimized energy management system.

\section{The Solar PV System}

The solar PV system is a technology that converts daylight (sun radiation) into power electricity by semiconductors. The solar PV cells area unit are usually found connected to form a framework known as a module. Multiple modules area unit are usually wired on to form associate array, which could be scaled up or down. In order to prove the quantity of power needed, PV cells area unit are usually manufactured from varied semi-conductor materials. The foremost usually used material these days is semiconductor, but various materials like; mono-crystalline silicon, polycrystalline silicon, 3-Amorphous silicon, Cadmium Telluride (CdTe), and Copper Indium Gallium 
Serenade (CIGS), are been examined and accustomed to increase the efficiency of converting solar energy into electricity [27, 28]. A typical solar PV is shown in Fig. 1(a) [29], where a semiconductor usually of silicon type is sandwiched between a negative conductor and a positive conductor. The basic arrangement of the solar PV system for electricity generation is shown in Fig. 1(b).

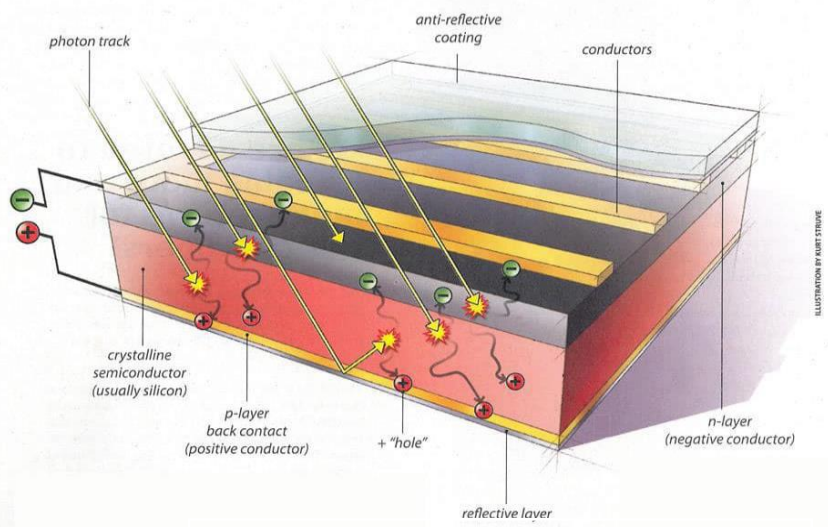

Fig. 1(a). Typical solar PV system

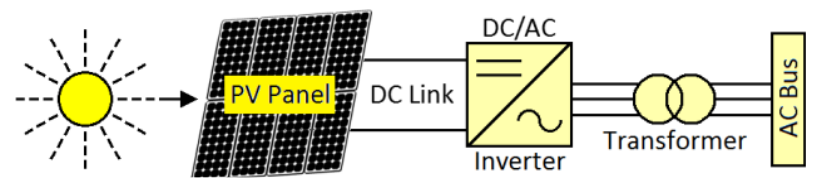

Fig. 1(b). Basic arrangement of solar PV

Factors affecting the performance of solar $P V$

The following are some of the factors that affect the performance of a solar PV. The performance of the PV output depends on temperature. Variations in temperature influence the performance parameters $[30,31]$. The impacts of temperature on current, voltage and power output of the PV cell are shown in Fig. 2 [32]. From the normalized values of current, voltage and power at $25^{\circ} \mathrm{C}$, with a rise in temperature, cell current will increase slightly, however the voltage drops at a high rate, resulting in the drop of the power output. If cell temperature falls below $25^{\circ} \mathrm{C}$, the current drops slightly, however the voltage and power will increase respectively.

Dust is another major factor that affects the performance of the solar PV. This occur naturally due to the position of the installed PV on roofs. The layer of the dirt on the solar array increases with time, and is usually measured in micrometers [33]. Also, shade is a necessary parameter that affects the output performance of the PV module. Shading is caused by numerous factors like presence of the tall building, leaves falling, fog, cloud, dirt particles, bird's excretory product, e.t.c. Reference [34] shows that with a rise within the share shading, the potency of the PV module decreases.

\section{Overview of generation costs for new capacity in Oman}

Figure 3 shows the relationship between the cost of generation for conventional plants, wind turbines at specific sites, a 20MW solar thermal plant and the grid connected 20MW PV plant [9]. The figure shows that solar systems wind power is the most competitive of the renewable energy sources in Oman, compared to the other renewable source.

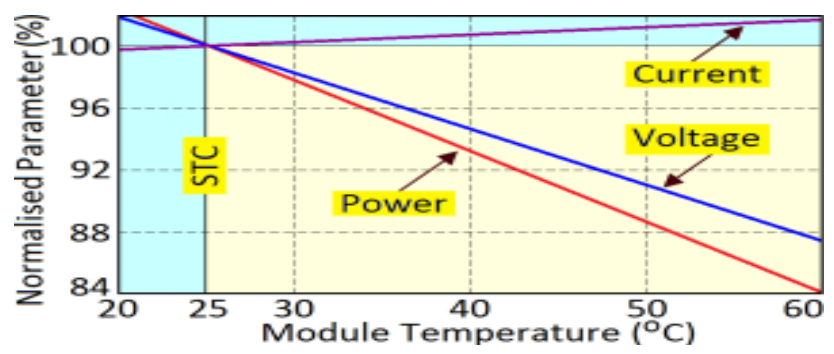

(a) Module parameters

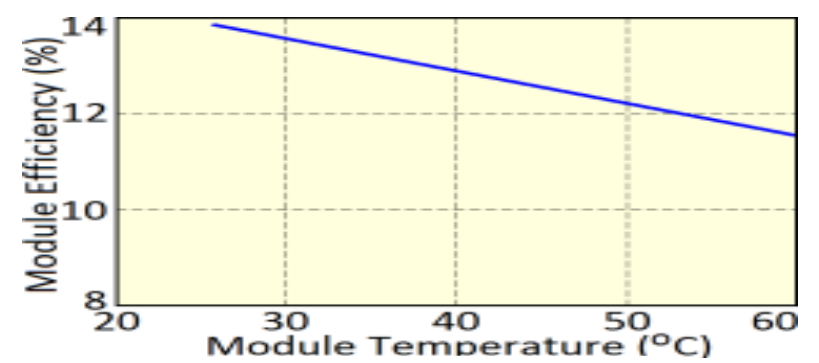

(b) Module efficiency

Fig. 2. Impacts of temperature on solar PV cell performance

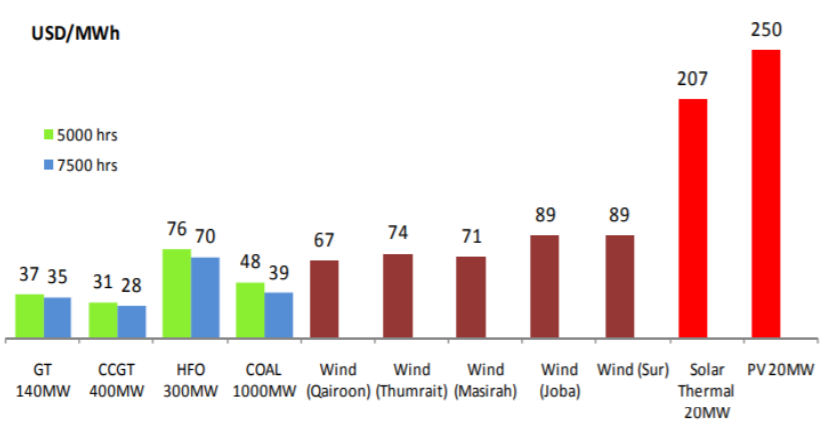

Fig. 3. Generation costs overview for new capacity in Oman

\section{Case study of Solar PV Penetration in Oman}

Shell Petroleum Company in collaboration with the headquarters of the ministry of higher education, considered installation of solar energy in schools from each Governorate in the Sultanate of Oman; Nizwa, AL Buraime and Salalah. The Hossam Technology Company (HTC), one of the local companies in the Sultanate, implemented the installation of solar energy system in the schools, with the completion of about four of the projects. This study employs the meteoroligical monitoring system for solar PV schemes to monitor and carry out real time dynamic analysis of the performance of the solar energy system in the Kaab bin Barsha school, used as case study for this work. The system virtual communication (VCOM) program features direct follow-up of energy readings generated by the solar radiation system. It is also able to follow all the required information through the online real time analysis, in addition to the features that enables the location of the school through Google Map. The location of the Kaab bin Barsha School considered is shown in Fig. 4a, while Fig. 4b shows its 
overview. The system profile of the Kaab bin Barsha School is shown in Fig. 5a, with $151.22 \mathrm{KW}_{\mathrm{P}}$ as the peak power of the photovoltaic system, commissioning date, inverter model and modules of the solar PV. The distributed energy generation of the solar PV is given in Fig. 5b, where the readings were obtained on 23 November, 2019.

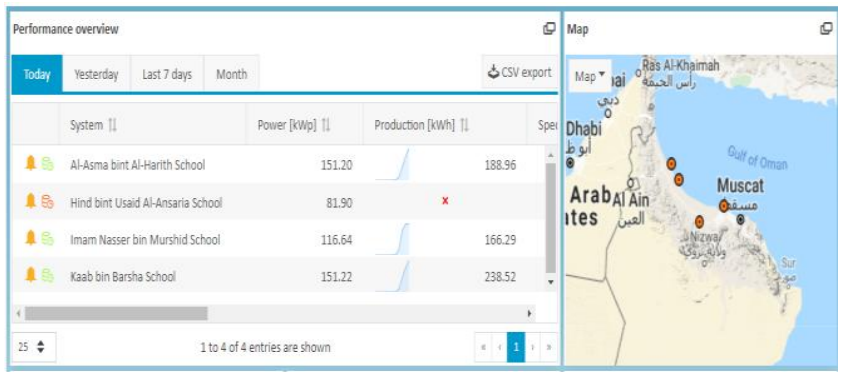

(a) Location of the case study

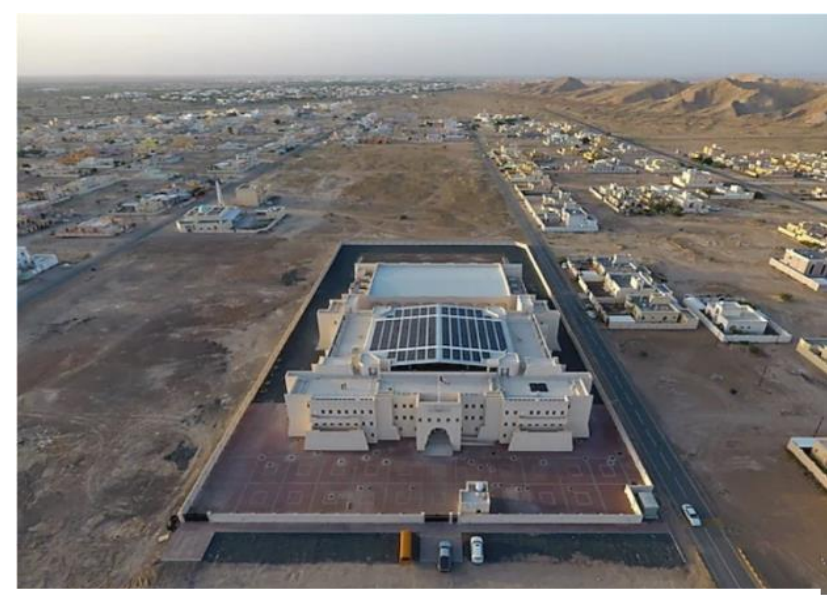

(b) Solar PV penetration in Kaab bin Barsha School

Fig. 4. Preview of the case study

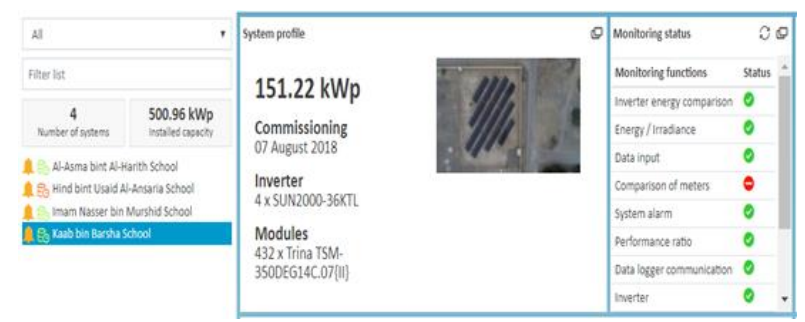

(a) System profile for Kaab bin Barsha School

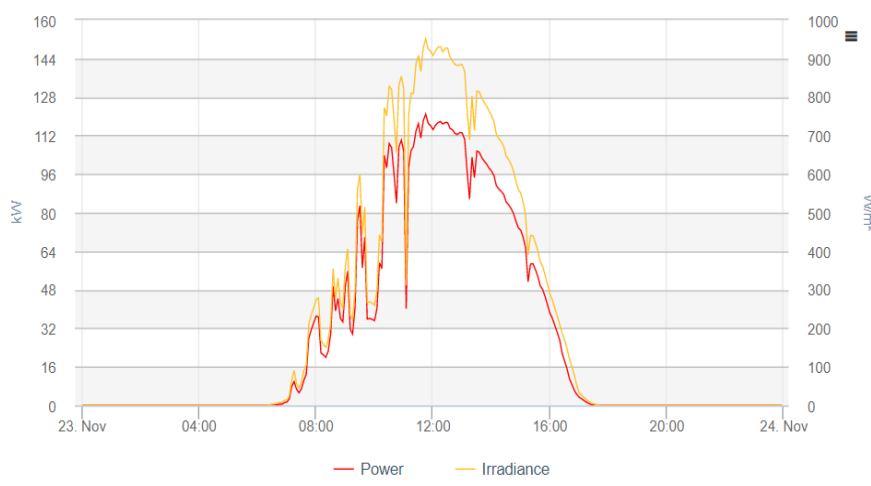

(b) Solar energy generation

Fig. 5. Variables of the case study
The sunrise is around 6:30am and from the chart the solar energy produced is $0.01 \mathrm{~kW}$ of power at that time. As the sunshine increases, the power gradually increases. However, the day the study was carried out (23 November, 2019) was cloudy, therefore the cloudy weather affected the solar energy production. At 11:45am, the power obtained reached $120.88 \mathrm{~kW}$ and irradiance $950.93 \mathrm{~W} / \mathrm{m}^{2}$. The minimum value of power reached was $0.00 \mathrm{~kW}$ at $17: 35 \mathrm{pm}$.

\section{Numerical and dynamic evaluation of the system performance}

The evaluation of the dynamics of the system is carried out considering the real time analysis on the penetration of the solar PV system on the 23 November, 2019. Figure 6 shows the dynamics of the solar PV system. In Fig. 6a, the parameters of the variables on a daily basis are as follows; the sum of the global radiation for the case study is 5.14 $\mathrm{kWh} / \mathrm{m}^{2}$, energy is $666 \mathrm{kWh}$, specific energy is 4.40 $\mathrm{kWh} / \mathrm{kWp}$ and nominal output power is $151.22 \mathrm{KWp}$. The maximum value unit for sum of global radiation and energy are $950.98 \mathrm{~W} / \mathrm{m}^{2}$ and $120.88 \mathrm{~kW}$, respectively. The responses of the net and solar active powers of the system during the peak of operation at 11.40am are given in Fig. 6b. In Fig. 6c, the solar power of the system with the losses incurred in the course of operation, the irradiance and the expected or target power is shown. The solar power is more than the expected target, hence there is need to utilize more solar generated power, either by connecting more loads or actively store the excess generated power for later use in order to optimize the generated energy. Fig. 6d shows the energy variance analysis of the system, with the variance maximum range of $90 \%$ to $115 \%$, and no energy variance between $0 \%$ and $70 \%$. In Figs 6e the mean efficiency for the month and year are $15 \%$ and $15.2 \%$, while the maximum efficiency for the month and year are $18.2 \%$ and $20 \%$ respectively. In Fig. 6f, the nominal power for the system is $151.22 \mathrm{kWp}$ as shown also in Fig. 4, with a maximum power in day and month as $120.9 \mathrm{~kW}$ and $128.6 \mathrm{~kW}$. The maximum irradiance for the day and month are $951 \mathrm{~W} / \mathrm{m}^{2}$ and $1014 \mathrm{~W} / \mathrm{m}^{2}$ respectively. The key performance indicators of the system are given in Fig. 7. In Fig. 7a, the monthly PV yield counter is $20,726.50 \mathrm{kWh}$ with maximum value of $799.25 \mathrm{kWh}$. However, the monthly simulated generated energy is $18,796.28 \mathrm{kWh}$ with maximum value of $723.31 \mathrm{kWh}$. Therefore, the energy performance index is $110.27 \%$ monthly, with maximum value of $112.79 \%$. The monthly performance ratio of the system in Fig. 7b shows $84.67 \%$, with a maximum value of $86.68 \%$. The figure also shows the specific energy yield of $157.06 \mathrm{kWh} / \mathrm{kWp}$, with a maximum value of $5.29 \mathrm{kWh} / \mathrm{kWp}$. The power performance and the PV system availability in Figs. $7 \mathrm{c}$ and $7 \mathrm{~d}$ reflect that the solar $\mathrm{PV}$ has high performance since it is always available in the region of the study. The AC power index and DC voltage are shown in Figs. $8 \mathrm{a}$ and $8 \mathrm{~b}$ respectively. The least mean AC inverter voltage value is around $252.15 \mathrm{~V}$ and a maximum value of 263.60 V is obtainable. In Fig. 8b, the DC power reflects a sharp transient of the DC voltage strings around 7:50am and $5 \mathrm{pm}$ in the DC power variable of the system, due to occurrence of cloud during that time of operation. However, the steady state was maintained in other- 


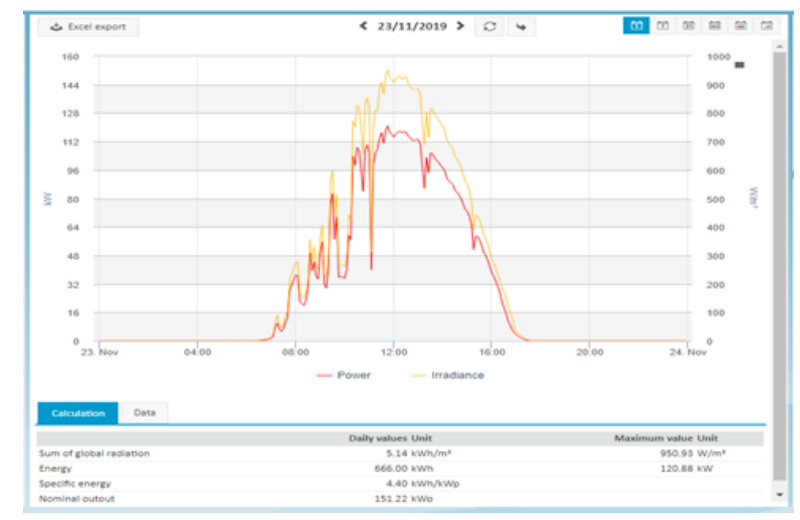

(a) Solar energy

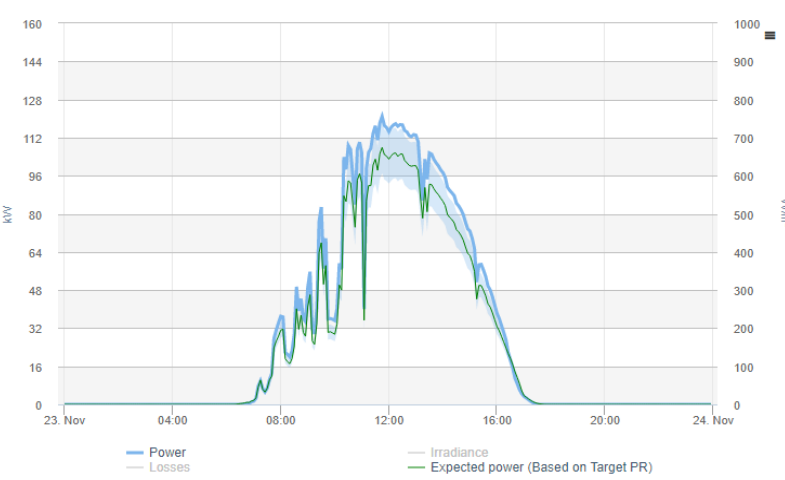

(b) Solar power

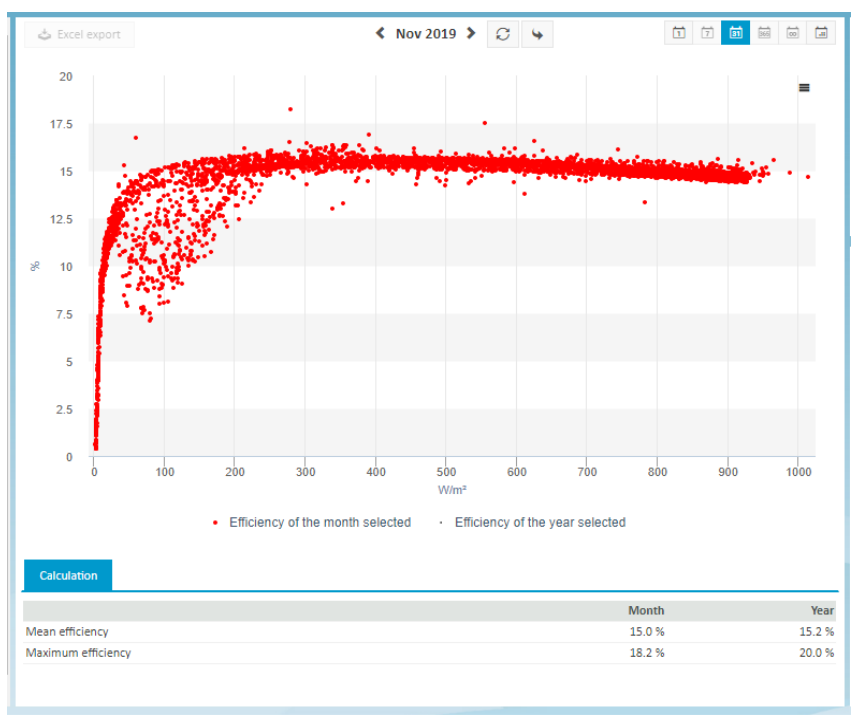

(c) System efficiency

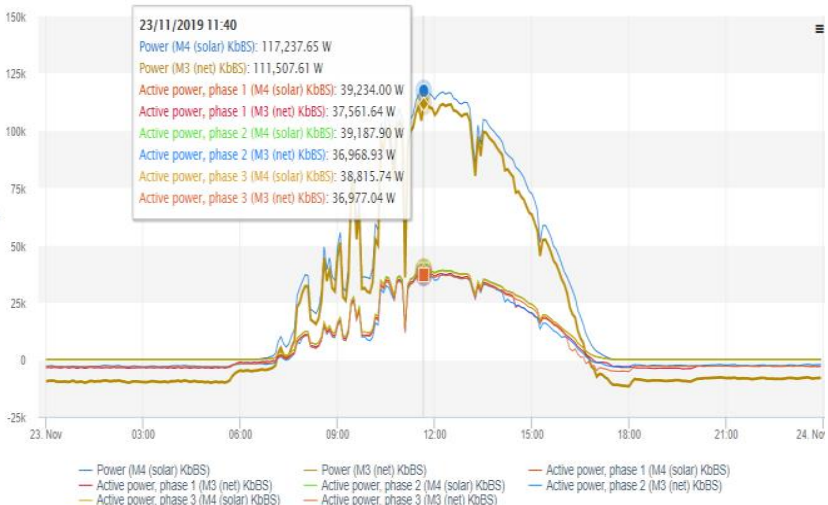

(d) Active power

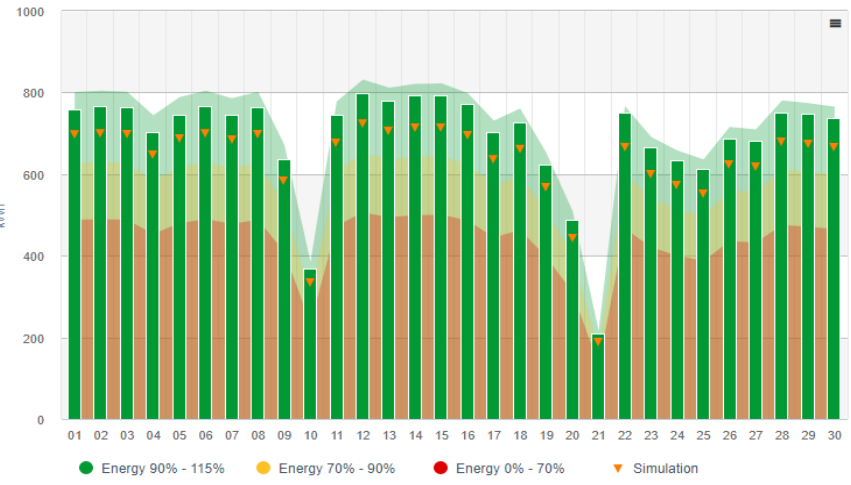

(e) Energy variance analysis

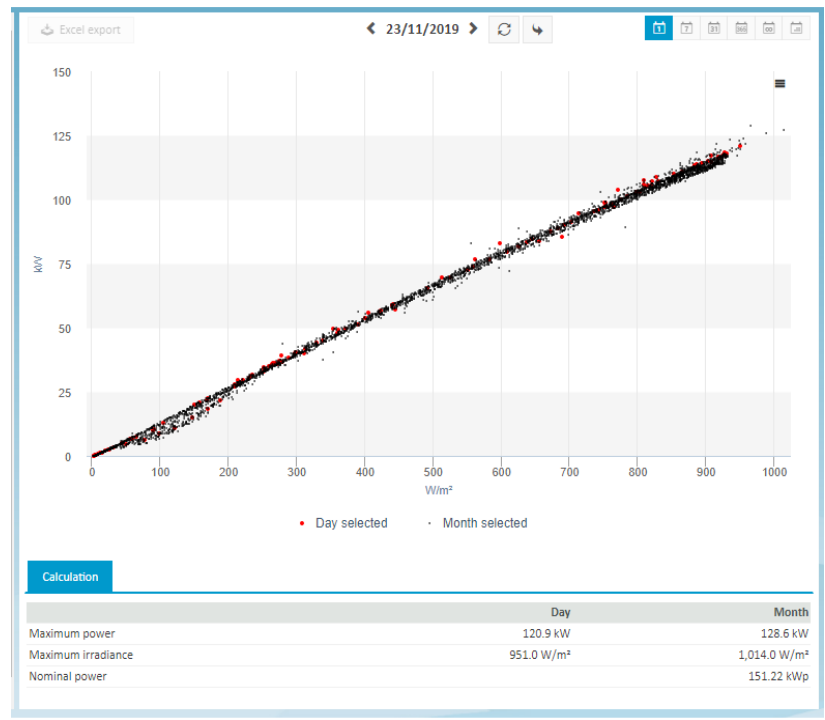

(f) Input and output power

Fig. 6. Dynamics of the solar PV system

-times of operation of the system. The grid frequency was maintained at $50 \mathrm{~Hz}$ and the reactive power dissipation was maintained at $0 \mathrm{pu}$ based on the stipulated grid codes or requirement for the grid operations in Figs. 8c and 8d, respectively. More reactive power was dissipated around 7:50am to maintain the grid disturbance that occurred in the system. The energy of the inverter system is shown in Fig. 8e, while their respective temperatures are given in Fig. $8 \mathrm{f}$.
The peak energy is around $200 \mathrm{kWh}$, at which the inverter temperature can get to slightly over $52.5^{\circ} \mathrm{C}$. Figure 9 shows the energy performance index of the system. The net energy generated for interval sourced is shown in Fig. 9a, while the net energy generated per interval supplied is shown in Fig. 9b. From Fig. 9, the sourced energy is about $120 \mathrm{kWh}$, while the supplied energy is about $650 \mathrm{kWh}$. 
INTERNATIONAL JOURNAL Of SMART GRID

Kenneth E. Okedu et al., Vol.4, No.2, June, 2020

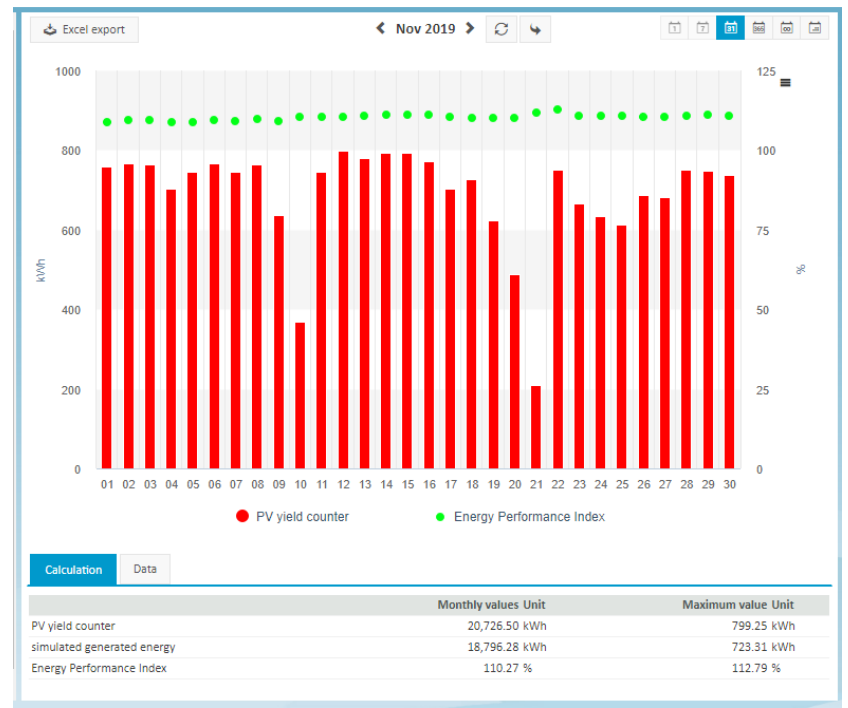

(a) Energy performance index

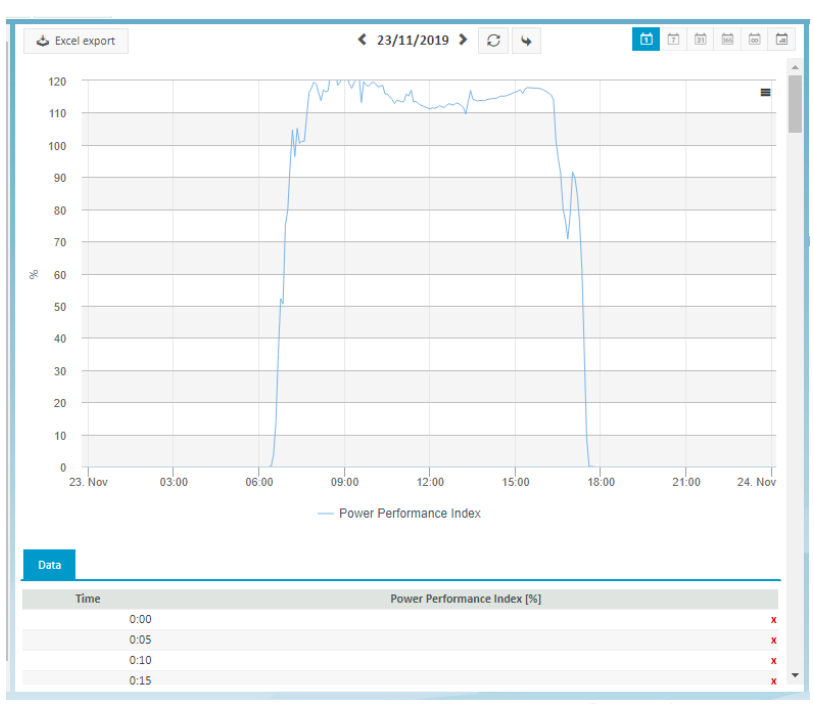

(b) Power performance

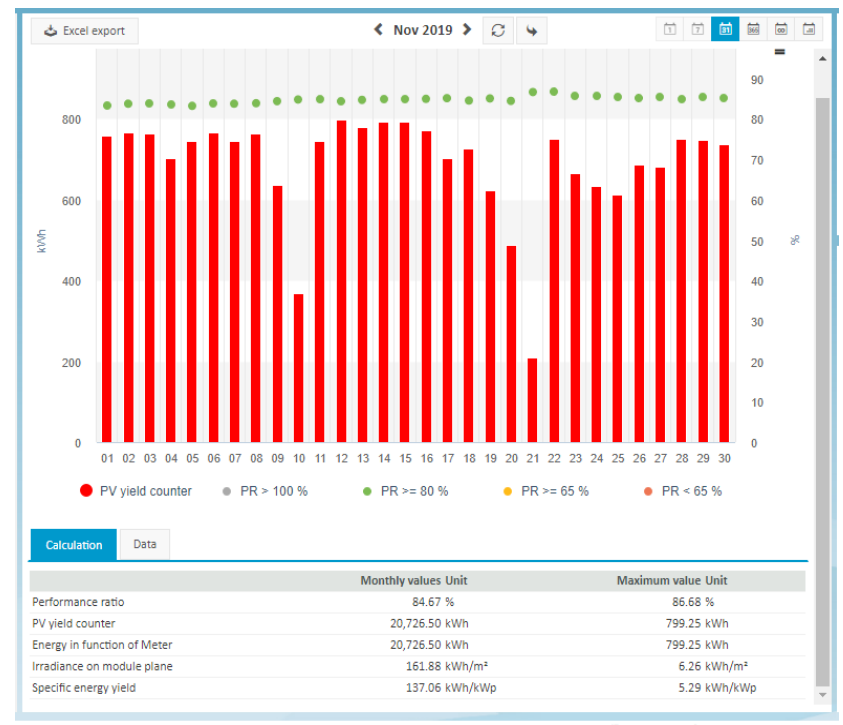

(c) Performance ratio

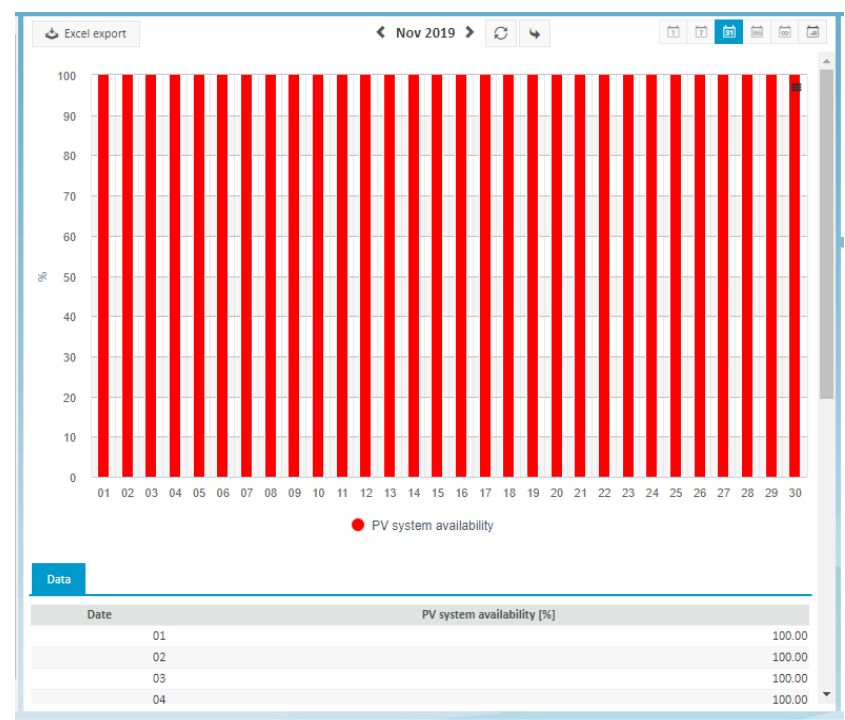

(d) System availability

Fig. 7. Key performance indicators

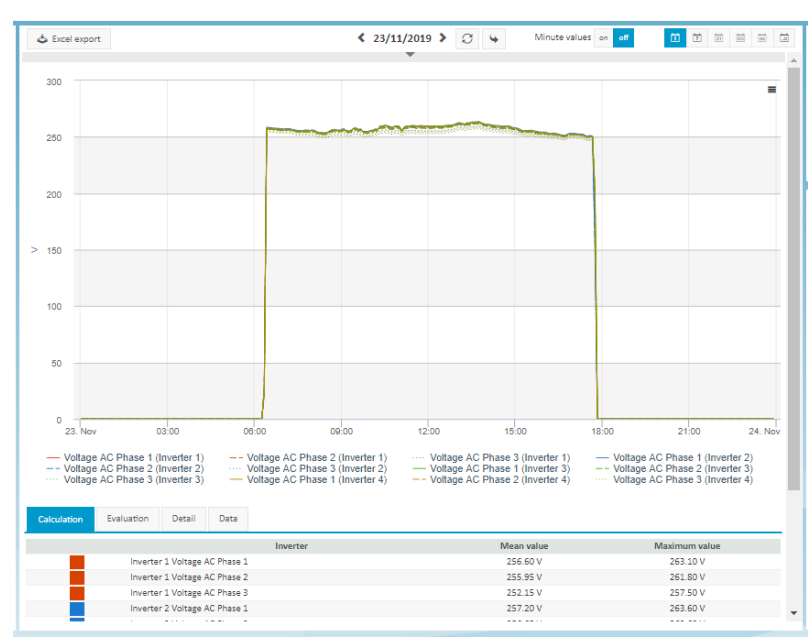

(a) AC power performance

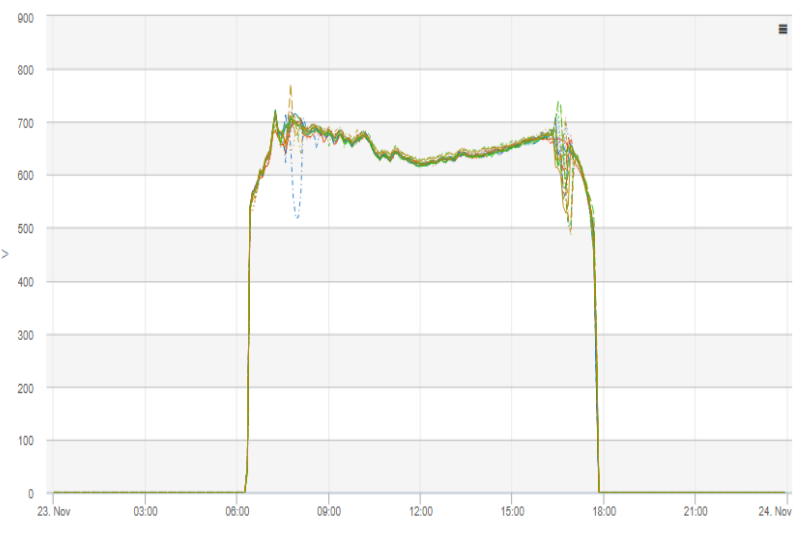

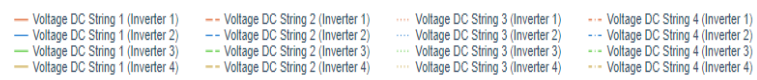

(b) DC voltage 


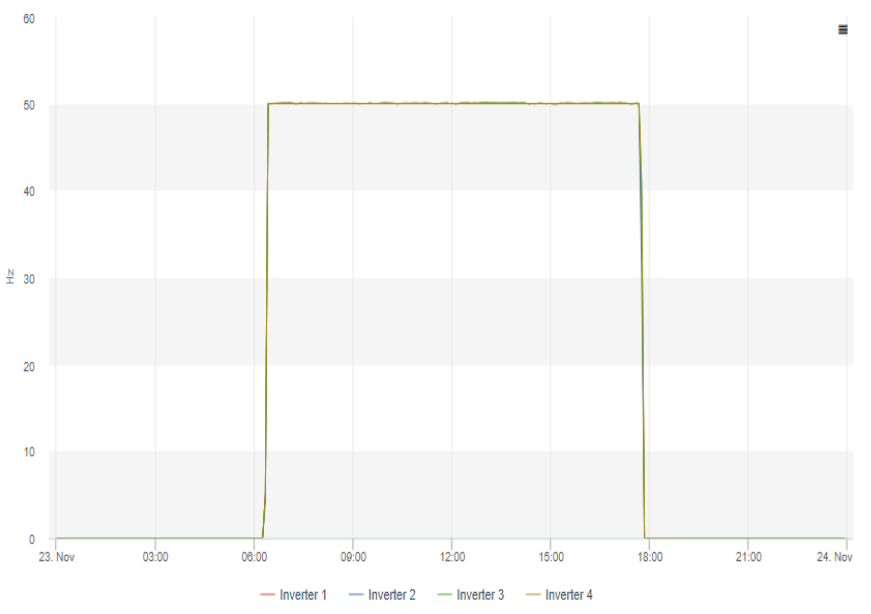

(c) Frequency

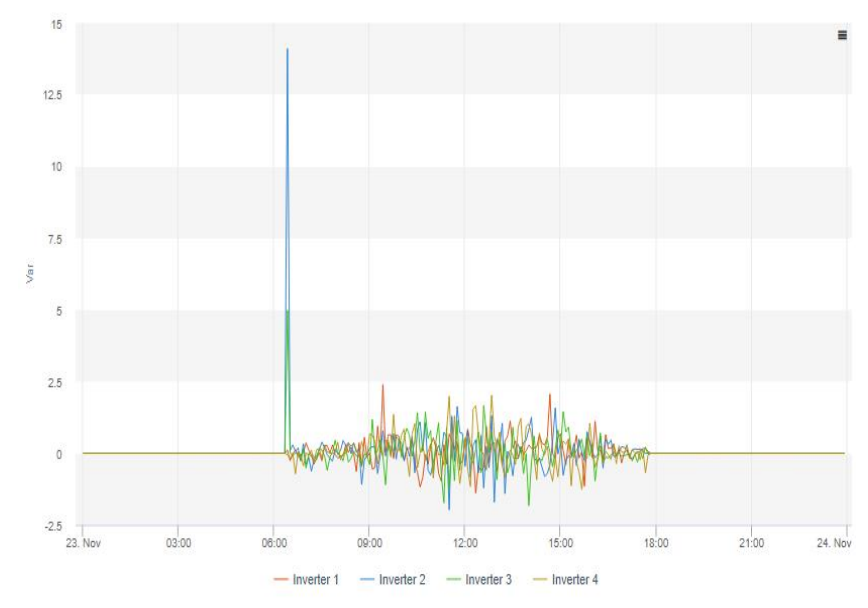

(e) Reactive power

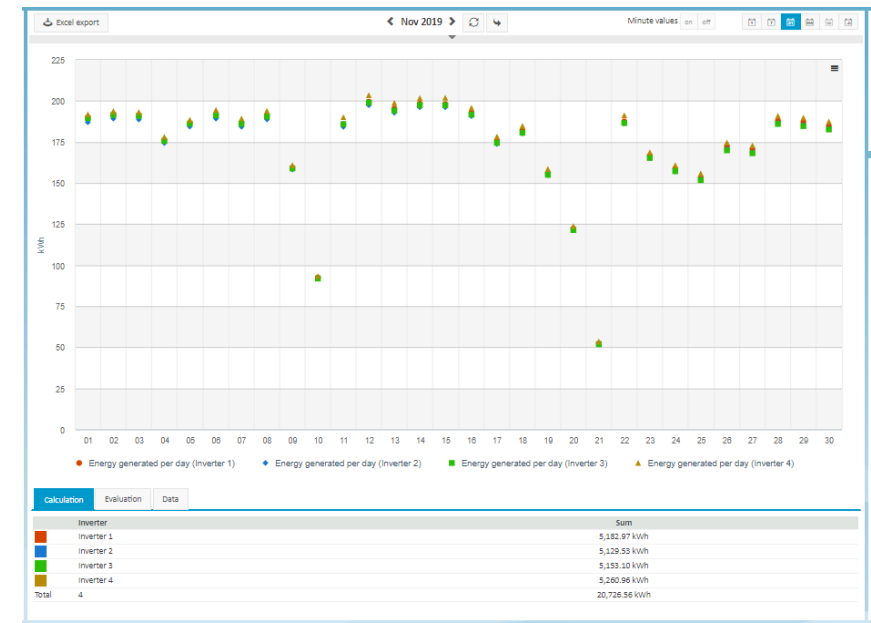

(d) Energy of inverter

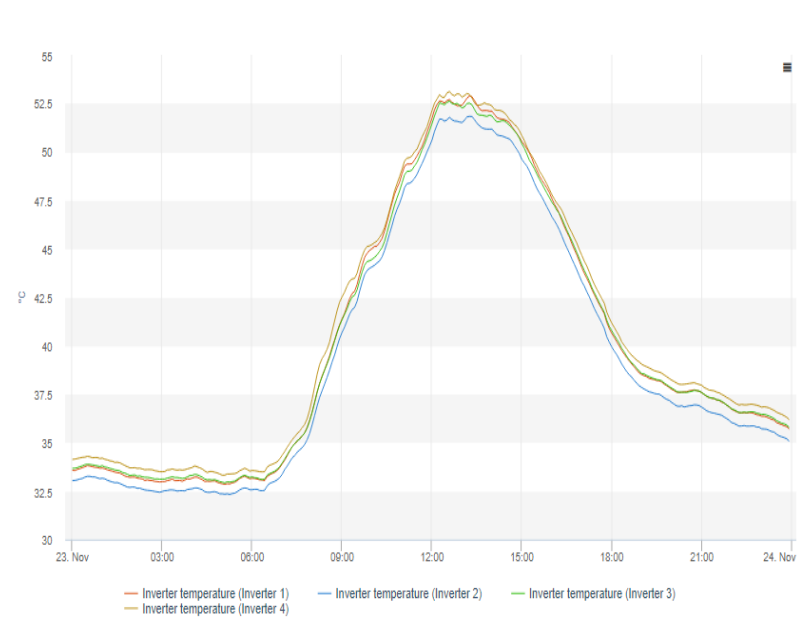

(f) Temperature

Fig. 8. Dynamics of the system variables

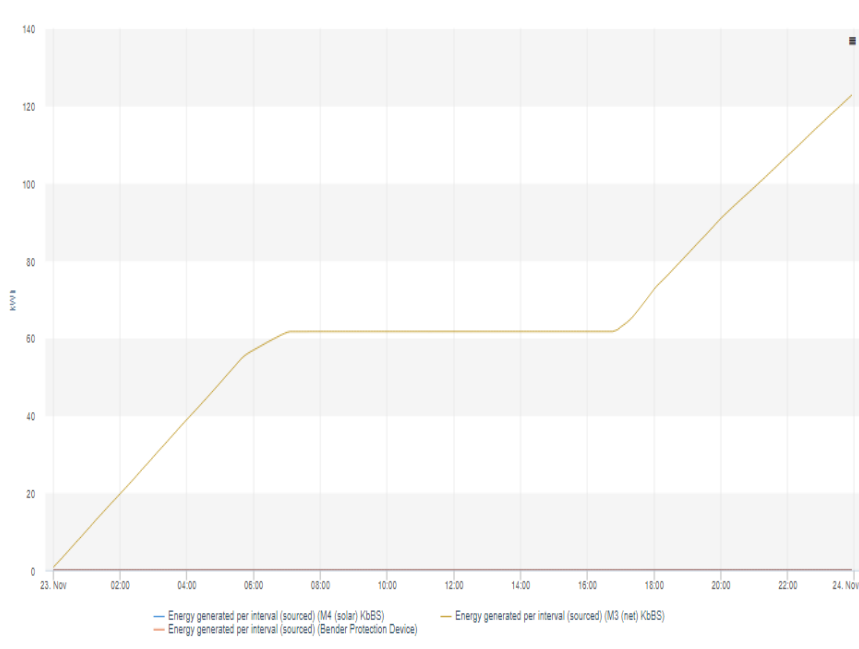

(a) Energy sourced

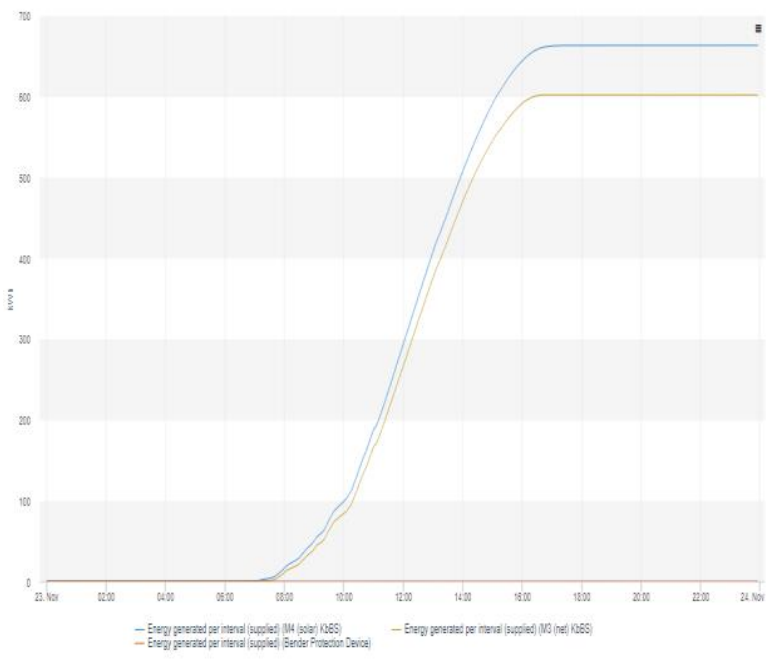

(b) Energy supplied

Fig. 9. Energy performance index 


\section{Comparison of energy generated and consumed for optimization and sales of electricity}

A comparison was carried out for three periods with different temperatures in the year of study, to estimate the power required for the loads at different times of the year in real time analysis, in order to optimize power generation and consumption for future load demand. Three scenarios were considered for this analysis as shown in Figs 10 to 12. In scenario 1, the analysis was carried out on 23 January, 2019 with the solar PV providing the power to the school used for the case study. Due to the fact that this period is warm (winter) in the Sultanate, the maximum inverter temperature is around $51^{\circ} \mathrm{C}$, as shown in Fig. 10a. Consequently, the school takes only $45 \%$ of power from solar energy and 55\% from the local grid system as shown in Fig. 10b. Therefore, through the help of the net metering system, the school administrator can save money from the power generated by using solar power. Furthermore, for scenario 2, on the 28 June, 2019, the temperature in summer time of June is very high with inverter temperatures as shown in Fig. 11a getting to over $72^{\circ} \mathrm{C}$. The solar power generated only $38.64 \%$ as shown in Fig. 11b, because it was a cloudy day, however, for a non-cloudy day on June 23, the solar power produced $57 \%$, while the local grid is $43 \%$ as shown in Fig. 11c. The effect of the clouds on the operation of the solar PV is also reflected in Figs 11d and 11e, respectively. With the presence of the cloud in Fig. 11d, the dynamics of the solar PV variables were not smooth in operation compared to Fig. 11e. Again, for scenario 3, the analysis was done for 23 November, 2019, where the temperature is slightly higher than winter with value of about $50^{\circ} \mathrm{C}$, as shown in Fig. 12a. From Fig. 12b, the solar power consumption for this scenario is $42 \%$, with local energy consumption of $58 \%$.

A summary of the percentage of the solar energy obtained in the school for the three considered months is shown in Fig. 13. From Fig. 13, solar energy provided power to the school in January 22\%, June 49\% and November 29\% respectively, for the year 2019. In June, the school has more percentage of solar energy because is summer and also due to the fact that schools are on long summer break, they are no load in the school such as air conditioners. Therefore, this period is the best time to optimize solar power production by selling electricity to the grid compared to other times like January and November. The lower solar power generation of $22 \%$ and $29 \%$ for January and November respectively, is due to winter period when the sun rays are low and the school is also on session with maximum load been on operation.

Scenario 1: 23 January, 2019

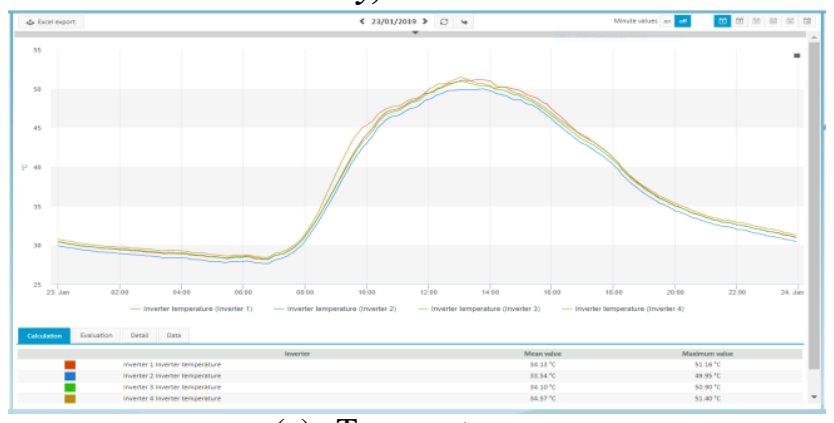

(a) Temperature

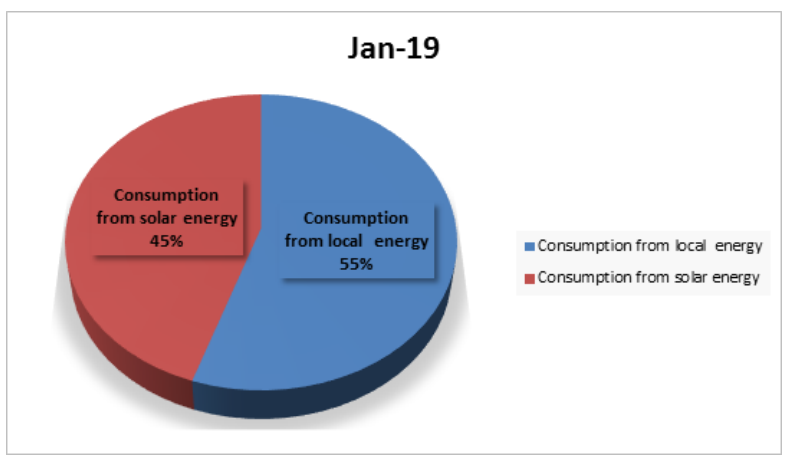

(b) Comparison of energy consumed for January

Fig. 10. Energy consumed at beginning of the year

Scenario 2: 23 June, 2019

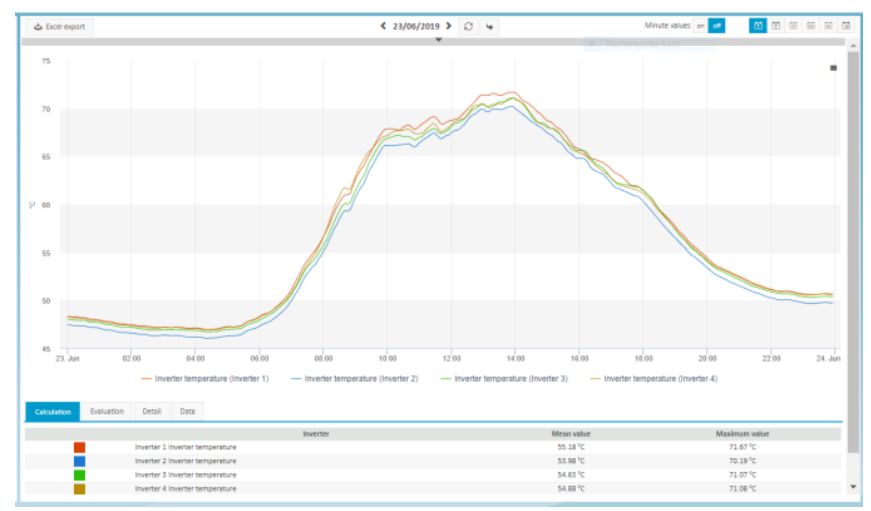

(a) Temperature

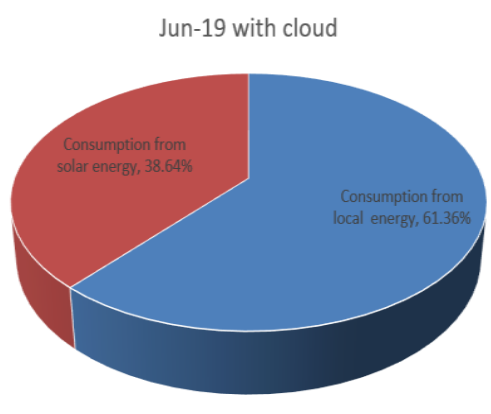

- Consumption from local energy I Consumption from solar energy

(b) Comparison of energy consumed for June during cloudy day

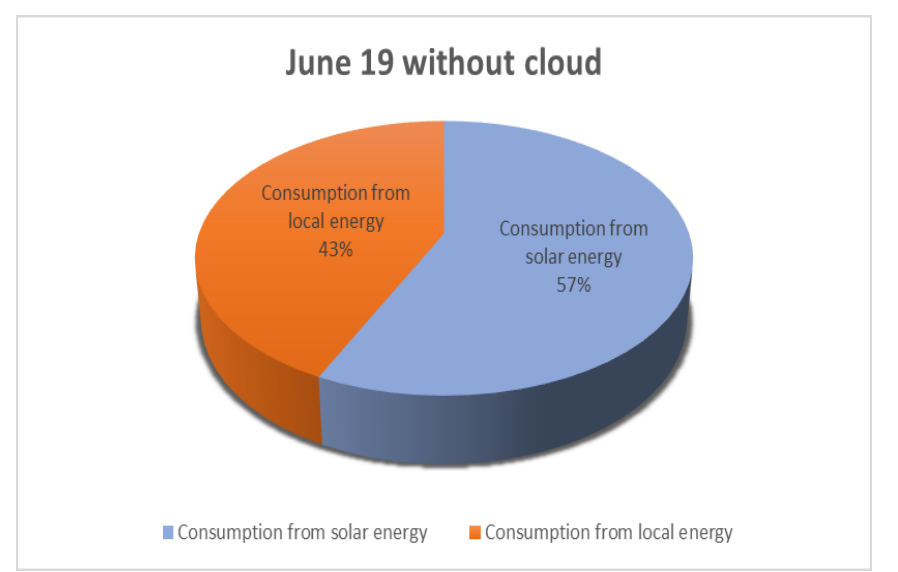

(c) Comparison of energy consumed for June during non-cloudy day 


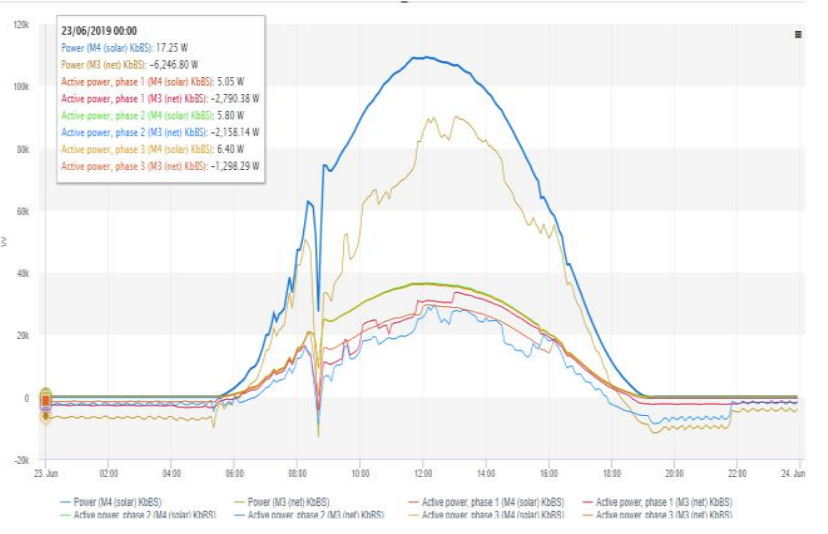

(d) Solar active power for June during cloudy day

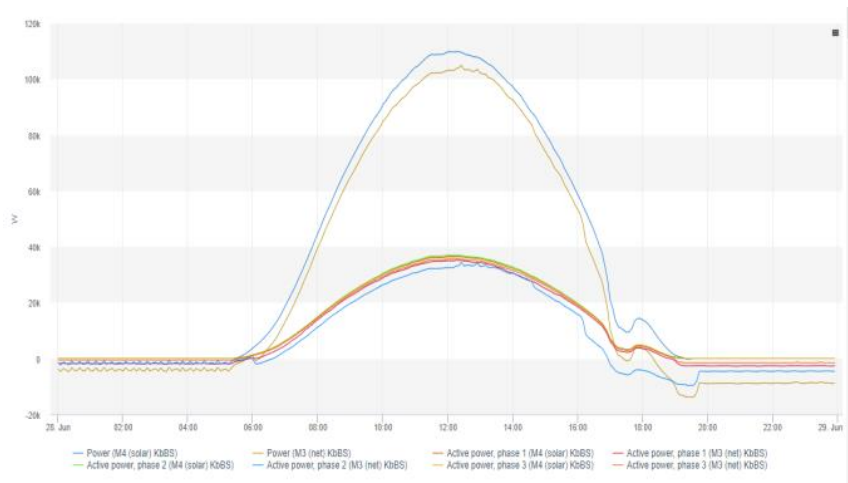

(e) Solar active power for June during non-cloudy day

Fig. 11. Energy consumed at middle of the year

\section{Scenario 3: 23 November, 2019}

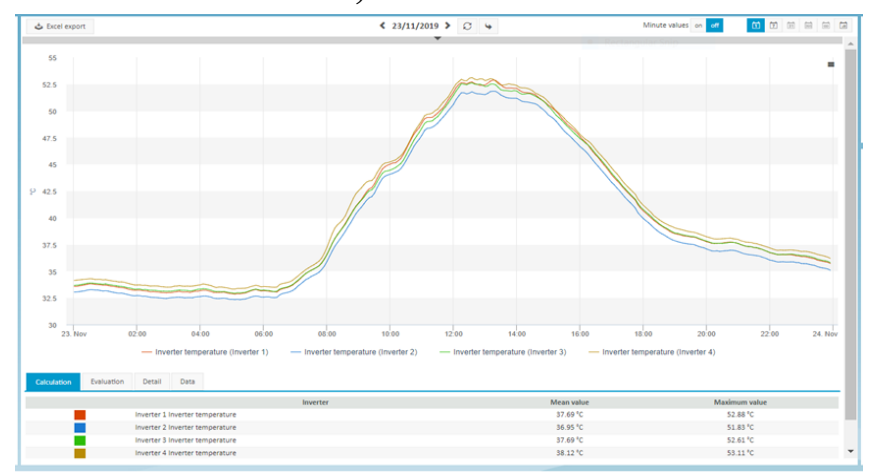

(a) Temperature

Nov-19

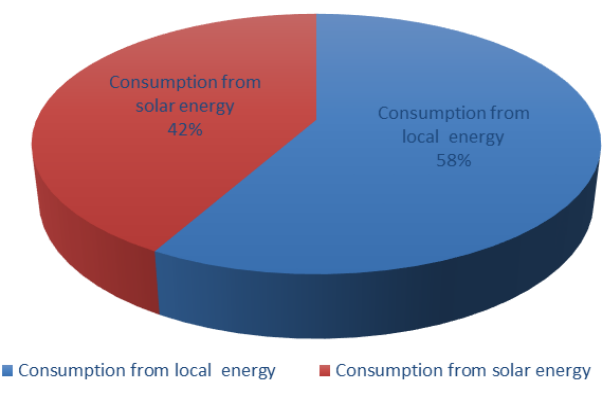

(b) Comparison of energy consumed for November

Fig. 12. Energy consumed at end of the year

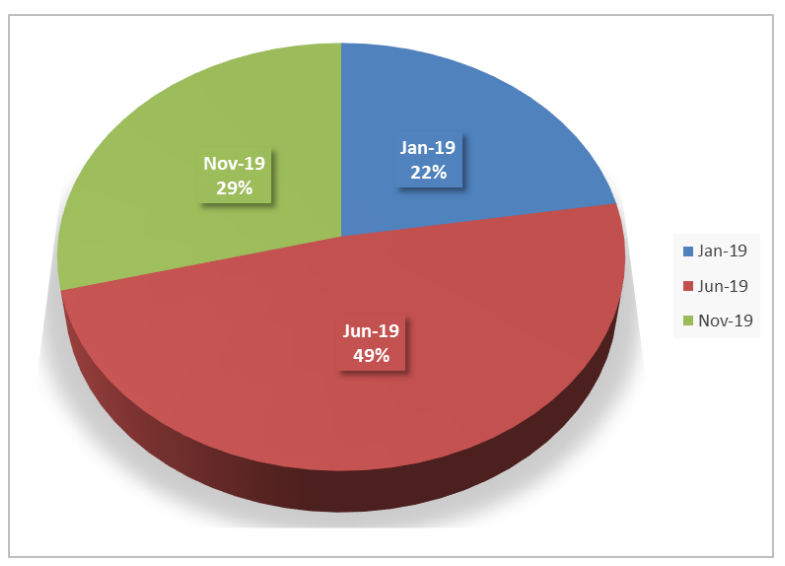

Fig. 13. Summary of Energy consumed throughout the year

The numerical index of the study is shown in Table 1 . From the presented results value, the solar power production is more than the solar power consumption with an approximate value of $1540.95 \mathrm{~W}$ for the case study. As shown in Table 1, the benefit of using the solar power is from 7:30am to $16: 30 \mathrm{pm}$. From 17:00pm, the solar power production is less than the solar power consumption with a value of $3578.134 \mathrm{~W}$. In this scenario, the system is working with batteries or energy storage devices.

\section{Economical analysis of the system}

Besides the PV performance analysis, an economic study was carried out, highlighting the possible advantages on selling electric power to the grid during the summer months as shown in Fig. 14. From the Fig. 14, the summer months from May through September, show high rate of return of solar PV investment. This is because much solar power was produced and exported into the grid, thus, saving more amount of money in Omani Rial. Although, in the months of October through December, the solar investment was high because no air conditioners and other cooling appliances were utilized these periods due to winter, unlike the summer period. From January to April, the PV investment was low.
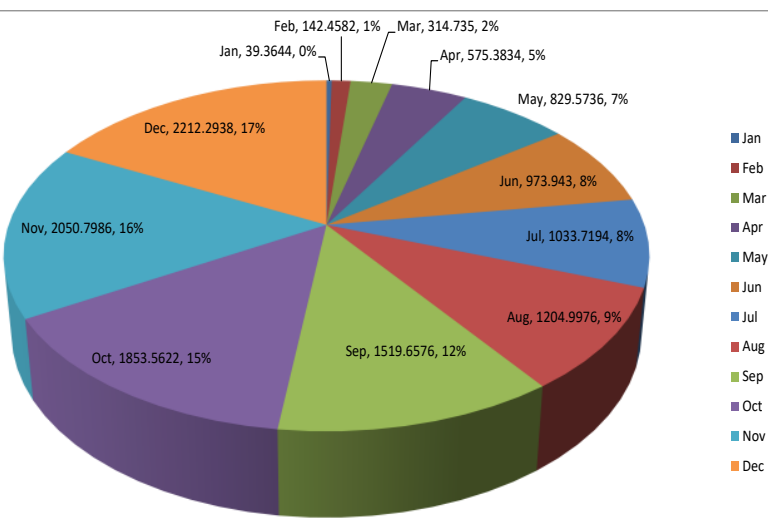

Fig. 14. Economic benefit of the solar PV grid system 
INTERNATIONAL JOURNAL Of SMART GRID

Kenneth E. Okedu et al., Vol.4, No.2, June, 2020

Table 1 Numerical index of the solar power production and consumption

\begin{tabular}{|c|c|c|c|c|c|c|c|}
\hline Time & $\begin{array}{l}\text { Power (M4 } \\
\text { (solar) } \\
\text { KbBS) }[\mathrm{W}]\end{array}$ & $\begin{array}{l}\text { Power (M3 } \\
\text { (net) KbBS) } \\
{[\mathrm{W}]}\end{array}$ & $\begin{array}{l}\text { The benefit } \\
\text { of solar [W] }\end{array}$ & Time & $\begin{array}{l}\text { Power (M4 } \\
\text { (solar) } \\
\text { KbBS) [W] }\end{array}$ & $\begin{array}{l}\text { Power (M3 } \\
\text { (net) KbBS) } \\
{[\mathrm{W}]}\end{array}$ & $\begin{array}{l}\text { The benefit } \\
\text { of solar [W] }\end{array}$ \\
\hline $0: 00$ & 6.238 & -9525.942 & -9519.704 & $12: 00$ & 113467.57 & 106691.82 & 220159.39 \\
\hline $0: 30$ & 9.612 & -9670.664 & -9661.052 & $12: 30$ & 116316.318 & 111247.816 & 227564.134 \\
\hline $1: 00$ & 7.88 & -9759.524 & -9751.644 & $13: 00$ & 112101.228 & 107134.352 & 219235.58 \\
\hline $1: 30$ & 8.056 & -9596.4 & -9588.344 & $13: 30$ & 104779.588 & 99372.42 & 204152.008 \\
\hline 2:00 & 10.554 & -9512.788 & -9502.234 & $14: 00$ & 96676.368 & 90806.586 & 187482.954 \\
\hline $2: 30$ & 8.136 & -9985.426 & -9977.29 & $14: 30$ & 83949.136 & 72842.926 & 156792.062 \\
\hline 3:00 & 8.318 & -9765.562 & -9757.244 & $15: 00$ & 72339.572 & 63188.712 & 135528.284 \\
\hline $3: 30$ & 9.86 & -9738.902 & -9729.042 & $15: 30$ & 56225.862 & 49873.48 & 106099.342 \\
\hline 4:00 & 9.042 & -9423.392 & -9414.35 & $16: 00$ & 38222.666 & 32775.014 & 70997.68 \\
\hline $4: 30$ & 10.118 & -9570.326 & -9560.208 & $16: 30$ & 18550.194 & 9344.498 & 27894.692 \\
\hline 5:00 & 10.266 & -9703.996 & -9693.73 & $17: 00$ & 3578.134 & -7490.554 & -3912.42 \\
\hline $5: 30$ & 12.73 & -10022.088 & -10009.358 & $17: 30$ & 204.658 & -10954.104 & -10749.446 \\
\hline 6:00 & 16.05 & -4740.096 & -4724.046 & $18: 00$ & 8.654 & -11654.376 & -11645.722 \\
\hline $6: 30$ & 197.774 & -4762.316 & -4564.542 & $18: 30$ & 11.694 & -9092.952 & -9081.258 \\
\hline 7:00 & 1540.95 & -3519.972 & -1979.022 & 19:00 & 14.496 & -9139.038 & -9124.542 \\
\hline $7: 30$ & 7046.226 & 2111.61 & 9157.836 & $19: 30$ & 12.482 & -8955.952 & -8943.47 \\
\hline 8:00 & 37071.632 & 31996.974 & 69068.606 & $20: 00$ & 21.714 & -8956.916 & -8935.202 \\
\hline $8: 30$ & 29802.456 & 25178.844 & 54981.3 & $20: 30$ & 13.482 & -8022.33 & -8008.848 \\
\hline 9:00 & 49208.602 & 44687.33 & 93895.932 & 21:00 & 11.39 & -8057.894 & -8046.504 \\
\hline $9: 30$ & 82085.556 & 77392.88 & 159478.436 & $21: 30$ & 17.022 & -8125.308 & -8108.286 \\
\hline $10: 00$ & 35264.748 & 29180.554 & 64445.302 & $22: 00$ & 13.394 & -8126.398 & -8113.004 \\
\hline $10: 30$ & 107946.234 & 100940.822 & 208887.056 & $22: 30$ & 14.698 & -8377.59 & -8362.892 \\
\hline 11:00 & 104270.266 & 99174.512 & 203444.778 & 23:00 & 9.194 & -8011.988 & -8002.794 \\
\hline $11: 30$ & 115963.968 & 110679.868 & 226643.836 & $23: 55$ & 19.394 & -7875.038 & -7855.644 \\
\hline
\end{tabular}




\section{Conclusion}

In this paper, the integration of solar energy into the Omani national grid network considering real time analysis is carried out. This study employs the meteoroligical monitoring system for solar PV schemes to monitor and carry out real time dynamic analysis of the performance of the solar energy system in Kaab bin Barsha School, which is used as a case study for this work. The system virtual communication (VCOM) platform features, enabled the online real time analysis in addition to the features that enables the location of the school. The analysis of the performance of solar energy resources were carried out for different times of the considered year. During middle of the considered year, when the summer was at its peak in the Sultanate, more solar power was generated. However, due to long summer holiday breaks in Schools in this period, much of the generated solar power is not been utilized. Therefore, this study helps to determine the best time to buy or sell electricity to the local grid in order to optimize the use of electricity and also save or make money through electricity sales. Analysis was also carried considering cloudy and noncloudy days. During cloudy days, the variables of the system are affected and the performance of the solar PV system is reduced. Furthermore, the ministry of higher education in the Sultanate should encourage the interconnection of more schools in a micro grid network, in order to generate more solar power to cover different times of the year and neglect the use of the local grid in the near future. This would promote sustainable development, in addition to optimize the use of generated solar power and save cost in the long run.

\section{References}

[1]. K. E. Okedu, and R., Uhunmwangho, "Optimization of renewable energy efficiency using HOMER", International Journal of Renewable Energy Research vol. 4, no. 2, pp. 421427, 2014.

[2]. World Energy Market Report, Cable News Network, 2018.

[3]. Annual Report, The Petroleum Development Company of Oman, 2016.

[4]. Draft report of Amal East and West Steam Flood Project, Glass point Engineering, 2012.

[5]. Renewable Energy Report, Oman Electricity and Transmission Company, 2014.

[6]. Annual Report, 2017, Ministry of Man Power, Oman, 2017

[7]. R. Ferroukhi, N. NGhazal-Aswad, S. Androulaki, D. Hawila, and T. Mezher, "Renewable energy in the GCC: Status and challenges", Int. J. Energy Sect. Manag., vol. 7, no. 1, pp. 84-112, 2013.
[8]. W. E. Alnaser, N. W. Alnaser, "The status of renewable energy in the GCC countries", Renew. Sustain. Energy Rev. vol. 15, pp. 3074-3098, 2011.

[9]. Authority of Electricity Regulation- Oman, Study on Renewable Energy Resources, Oman, 2008.

[10]. A. Kazem, H. Abdullah, R. Hason, and A. AL-Waeli, "Prospects of Potential Renewable and Clean Energy in Oman”, IJECCT vol. 1, no 2, pp. 25-29, 2011.

[11]. Oman Power and Water Procurement Company, OPWP's 7-Year Statement, 2015.

[12]. Y. Al-Hatmi, and C. Tan, "Issues and challenges with renewable energy resources in Oman", IJRET vol. 2, no. 7, pp. 2319-1163, 2013.

[13]. International Renewable Energy Agency, Sultanate of Oman renewables readiness assessment, 2014.

[14]. Oxford Institute for Energy Studies, Prospects for renewable energy in GCC states opportunities and the need for Reform, 2014.

[15]. A. A. Mas'ud, A. V. Wirba, S. J. Alshammari, F. Muhammad-Sukki, M. M. Abdullahi, R. Albarracín and M. Z. Hoq, "Solar energy potentials and benefits in the gulf cooperation council countries: a review of substantial issues', Energies, vol. 11, pp. 372-392, 2018.

[16]. A. M. Ismail, R. Ramirez-Iniguez, M. Asif, A. B. Munir, F. Muhammad-Sukki, "Progress of solar photovoltaic in ASEAN countries: A review", Renew. Sustain. Energy Rev. vol 48, pp. 399-412, 2015.

[17]. S. Munawwar, H. Ghedira, "A review of renewable energy and solar industry growth in the GCC region," Energy Procedia, vol. 57, pp. 3191-3202, 2014.

[18]. International Renewable Energy Agency (IRENA), Renewable energy market analysis: The GCC Region. IRENA: Abu Dhabi, UAE, 2016.

[19]. Z. Abdmouleh, R. A. M. Alammari, A. Gastli, "Recommendations on renewable energy policies for the GCC countries," Renew. Sustain. Energy Rev., vol. 50, pp. 1181-1191, 2017.

[20]. J. I. Bachellerie, Renewable energy in the GCC countries: Resources, potential and prospects, 1st ed. Gulf Research Center: Jeddah, Saudi Arabia, ISBN 9789948490050, 2012.

[21]. K. E. Okedu, and M. Al-Hashmi, "Assessment of the Cost of various Renewable Energy Systems to Provide Power for a Small Community: Case of Bukha, Oman", International Journal of Smart Grid, vol.2, no. 3, pp. 172$182,2018$.

[22]. K. E. Okedu, and W. Z. AL Salmani, "Smart Grid Technologies in Gulf Cooperation Council Countries: 
Challenges and Opportunities", International Journal of Smart Grid, vol.3, no. 2, pp. 92-102, 2019.

[23]. K. E. Okedu, H. AL Nadabi, A. Aziz, "Prospects of Solar Energy in Oman: Case of Oil and Gas Industries", International Journal of Smart Grid, vol.3, no. 3, pp. 138$151,2019$.

[24]. Gulf Cooperation Council (GCC), Accessed on 6 November 2017.

[25]. Holland+You, Opportunities for Dutch Business in the Gulf Region; Holland+You: The Hague, The Netherlands, 2016.

[26]. R. Ferroukhi, H. Doukas, S. Androulaki, E. Menichetti, A. Masini, A. Khalid, EU-GCC Renewable Energy Policy Cooperation: Exploring Opportunities. In EU-GCC Renewable Energy Policy Experts' Workshop; Gulf Research Center: Abu Dhabi, UAE, pp. 1-44, 2013.

[27] S. K. Jha, "Application of solar photovoltaic system in oman-Overview of technology, opportunities and challenges", International Journal of Renewable Energy Research, vol. 3, no. 2, 2013, pp. 331-340.

[28]. J. A. Luceño-Sánchez, A. M. Díez-Pascual, and R. P. Capilla, 'Materials for photovoltaics: State of art and recent developments', International Journal of Molecular Sciences, vol. 20, no. 4, 2013.

[29]. R. S. Sankar, and S. V. J. Kumar, "Stability Analysis of Grid Connected PV System", Journal on Electrical Engineering, pp. 7-28, 2017.

[30]. M. A. P. Mahmud, N. Huda, S. H. Farjana and C. Lang, "Environmental impacts of solar-photovoltaic and solarthermal systems with life-cycle assessment", Energies, vol. 11 , no. $9,2018$.

[31] N. S. Mohd Hussin, N. A. Mohd Amin, M. J. A. Safar, R. S. Zulkafli, M. S. A. Majid, M. A. Rojan and I. Zaman, "Performance Factors of the Photovoltaic System: A Review”, MATEC Web of Conferences, 225, pp. 1-8, 2018.

[32]. K. Vidyanandan, "An Overview of Factors Affecting the Performance of Solar PV Systems", Energy Scan, (February), pp. 2-8, 2017.

[33]. M. M. Rahman, M. A. Islam, A. Z. Karim, A. H. Ronee, "Effects of Natural Dust on the Performance of PV Panels in Bangladesh", International Journal of Modern Education and Computer Science, vol.4, no. 10, pp. 26-32, 2012.

[34]. A. Pradhan, and B. Panda, "Experimental analysis of factors affecting the power output of the PV module", International Journal of Electrical and Computer Engineering, vol. 7, no. 6, pp. 3190-3197, 2017. 